\title{
Determination of the Genetic Diversity of Different Bioluminescent Bacteria by Pulsed-Field Gel Electrophoresis (PFGE)
}

\author{
Esra Ersoy Omeroglu ${ }^{1, *}$ \\ ${ }^{1}$ Biology Department, Faculty of Science, Basic and Industrial Microbiology Section, Ege University, Bornova-Izmir, Turkey \\ ${ }^{*}$ Corresponding author: Esra Ersoy Omeroglu, Biology Department, Faculty of Science, Basic and Industrial Microbiology Section, Ege University, Bornova-Izmir, Turkey. Tel: \\ +90-2323112811, Fax:+90-2323881036, E-mail: esraerso@gmail.com
}

Received: March 2, 2015; Revised: April 26, 2015; Accepted: May 21, 2015

\begin{abstract}
Background: There are 4 different genera (i.e.Vibrio, Aliivibrio, Photobacterium, and Shewanella) in the new classification of bioluminescent bacteria. The mechanism of bioluminescence has yet to be fully elucidated. Therefore, the determination of physiological and genetic characteristics of bioluminescent bacteria isolated from different sources is very important. Pulsed-Field Gel Electrophoresis (PFGE) has the highest discriminatory power among the different molecular typing methods for the investigation of the clonal relationships between bacteria. For the PFGE analysis of bioluminescent bacteria, the Notl-HFF is the method of choice among the restriction enzymes. Objectives: The present study aimed to determine genetic relatedness via PFGE in 41 bioluminescent bacteria (belonging to 10 different species) isolated and identified from various marine sources.

Materials and Methods: Different bioluminescent bacteria (i.e. Vibrio gigantis, V. azureus, V. harveyi, V. lentus, V. crassostreae, V. orientalis, Aliivibrio logei, A. fischeri, Shewanella woodyi, and Photobacterium kishitanii) were analyzed by PFGE using the Notl-HF ${ }^{\mathrm{TM}}$ restriction enzyme. The whole DNA of the strains embedded into the agarose plugs was digested with enzyme at $37^{\circ} \mathrm{C}$ for 30 minutes. CHEF-Mapper PFGE system was used for electrophoresis and band profile of the strains for the NotI-HF ${ }^{\mathrm{TM}}$ restriction enzyme were analyzed by Bio-Profil-1D++ software(Vilber Lourmat) at 10\% homology coefficient.

Results: Although all experiments were performed three times, four of forty-one bioluminescent strains (V. gigantis E-16, H-16 and S3W46 strains and A. fischeri E-4 strain) could not be typed by PFGE technique with Notl-HF ${ }^{\mathrm{TM}}$ enzyme. While only two strains (V. crassostreae H-12 and H-19 strains) were exhibiting same band pattern profiles (100\% genome homology), thirty-six different PFGE band patterns were obtained. Pattern homologies changed between $66 \%-92 \%, 73 \%-83 \%$ and $49 \%-100 \%$ for V. gigantis, V. harveyi and other strains, respectively. Conclusions: The obtained results revealed that there has been a high rate of genetic diversity in bioluminescent strains isolated from Gulf of Izmir and $V$. lentus and $V$. crassostreae strains could be also bioluminescent for the first report. At the same time, PFGE analysis of bioluminescent bacteria including four different genera and ten different species were shown for the first time by this study. It is considered that data acquired by this study will contribute evolution and mechanism of bioluminescence to further works to be done.
\end{abstract}

Keywords: Pulsed-Field Gel Electrophoresis; Bioluminescent; Alivibrio; Shewanella; Vibrio; Photobacterium

\section{Background}

Until recently, there were only 3 known marine bioluminescent bacterial genera (i.e. Vibrio, Photobacterium, and Shewanella). Nevertheless, a study performed by Urbanczyk et al. in 2007 (1) revealed that the Vibrio fischeri species were different from the other genera of the Vibrionaceae family in terms of phylogenetic and phenotypic properties. Accordingly, $V$. fischeri and A. logei were reclassified into a new genus called Aliivibrio. In addition to the new classification and according to the results of some studies, the new bioluminescent Vibrio and Photobacterium species were obtained. Up to 2007, only 15 bioluminescent species were known (i.e. V. cholerae, V. fischeri, V. harveyi, A. logei, V. mediterranei, $V$. orientalis, V. splendidus (biotype I), V. vulnificus, V. salmonicida, Photobacterium angustum, P. leiognathi, $P$. phosphoreum, P. mandapamensis, Shewanella hanedai, and S. woodyi) (2). Subsequent studies performed in 2007, 2009, and 2010 introduced 6 new bioluminescent species (i.e. $P$. kishitanii, P. aquimaris, V. azureus, V. sagamiensis, V. chagasii, and A. sifiae) (3-8). There was a special case for $V$. chagasii because when it was isolated for the first time, it was indicated that this Vibrio species was not bioluminescent (7). A similar situation was demonstrated in a study conducted by Ersoy Omeroglu and Karaboz in 2012 (9). Vibrio gigantis was first isolated by Le Roux et al. in 2005 (10) and is a member of marine bioluminescent bacteria (9). In 2014, this study was cited and it was indicated that the V. gigantis strains were bioluminescent (11). Because of such reasons, the systematic evaluation of bioluminescent bacteria has been regularly revised in terms of their taxonomy, evolutionary relationship, and origin.

The distribution of marine bioluminescent bacteria between all bacteria has yet to be fully elucidated. Marine bioluminescent genera (i.e. Vibrio, Aliivibrio, Photobacterium, and Shewanella) contain a large number of species which are both non-bioluminescent and closely associated with them. Additionally, it is thought that bioluminescent events may have evolved at least 40 times since their onset. Consequently, the isolation and identifica-

Copyright (C) 2015, Ahvaz Jundishapur University of Medical Sciences. This is an open-access article distributed under the terms of the Creative Commons Attribution-NonCommercial 4.0 International License (http://creativecommons.org/licenses/by-nc/4.0/) which permits copy and redistribute the material just in noncommercial usages, provided the original work is properly cited. 
tion of new bioluminescent genera or species from different sources and determination of their genetic diversity are very important. There are different molecular typing methods to investigate the clonal relationships between bacteria. Pulsed-Field Gel Electrophoresis (PFGE) has the highest discriminatory power of all of them. The salient disadvantage of this technique accepted as the gold standard is that the results cannot be compared with each other due to the implementation of dissimilar protocols in different laboratories. In addition, PFGE results in classical protocols as long as three or four days (12). In PFGE, as a consequence of the cutting of the total genomic DNA by restriction endonucleases, PFGE fragment patterns are formed. For a large number of bioluminescent $(3,9,13-15)$ and non-bioluminescent bacteria (16), this technique has been used with different restriction enzymes.

\section{Objectives}

To the best of our knowledge, the existing literature contains no PFGE data performed with the NotI-HF ${ }^{\mathrm{TM}}$ restriction enzyme with different bioluminescent bacteria. Thus, in this study, we aimed to determine the genetic relatedness of 10 different bioluminescent species isolated and identified from various marine sources. The data obtained from this study could lead to a better understanding of the bioluminescence mechanism.

\section{Materials and Methods}

\subsection{Bioluminescent Strains}

Forty-one bioluminescent strains isolated from different seawater, sediment, and fish samples and collected from regions at discrete depths in the Gulf of Izmir were used for this study. The bioluminescent bacteria identified by phenotypic and molecular methods $(9,15,17)$ were streaked onto a Seawater Complete Agar (SWC) medium to obtain a single colony. After checking the purity of the strains, they were grown in a liquid SWC medium (18).

\subsection{Preparation of Bioluminescent Strains}

Bacterial suspensions with turbidity equivalent to McFarland 1.0 were prepared in $200 \mu \mathrm{L}$ HST buffer (cell suspension buffer) (10 mM Tris-HCl (Sigma-Aldrich, USA), 50 mM EDTA (Sigma-Aldrich, USA), and $20 \mathrm{mM} \mathrm{NaCl}$ (SigmaAldrich, USA)), and bacterial pellets were obtained by centrifuging at 13.000 grams for 2 minutes at $4^{\circ} \mathrm{C}$. After discarding the supernatants, the pellets were suspended in $200 \mu \mathrm{L}$ cold HST buffer (12).

\subsection{Embedding of Strains into Agarose Plugs}

Two percent low-melting agarose (Bio-Rad, USA) was prepared in the HST buffer. The agarose-buffer mixture was supplemented with $0.5 \mathrm{~mL}$ SDS (sodium dodecyl sulfate, Sigma-Aldrich; USA) (10 g/50 mL). Afterward, it was melted by heating in a magnetic stirrer at $50^{\circ} \mathrm{C}$. The agarose mould (10 $\mathrm{mm} \times 5 \mathrm{~mm} \times 1.5 \mathrm{~mm}$, Bio-Rad, USA) was kept at $4^{\circ} \mathrm{C}$. Thereafter, $1.5 \mathrm{~mL}$ tubes for each bioluminescent strain were placed into a dry heat block at $50^{\circ} \mathrm{C}$ and $100 \mu \mathrm{L}$ of an agarose-SDS mixture. Then, $100 \mu \mathrm{L}$ of the bacteria suspension in the HST buffer was transferred into them. Subsequently, they were transferred into the agarose moulds without air bubbles and put at $4^{\circ} \mathrm{C}$ for hardening for 10 minutes (12).

\subsection{Fractionation of Bacterial Cell into Agarose}

Cell lysis solution I (50 mM Tris-HCl, 50 mM EDTA, 2.5 mg/ $\mathrm{mL}$ lysosime (Sigma-Aldrich, USA) and $1.5 \mathrm{mg} / \mathrm{mL}$ proteinase K (Sigma-Aldrich, USA)) was prepared freshly. Agarose plugs with bacteria were removed from the moulds and placed into the lysis solution. All the tubes were incubated in a water bath at $37^{\circ} \mathrm{C}$ for 1 hour. After removing the cell lysis solution I, $600 \mu \mathrm{L}$ of cell lysis solution II was prepared freshly (50 mM EDTA, 1\% sarcosyl (Sigma-Aldrich, USA), and $400 \mu \mathrm{g} / \mathrm{mL}$ proteinase $\mathrm{K}$ ) and was added into the tubes, and they were incubated in a water bath at $55^{\circ} \mathrm{C}$ for 1 hour (12)

\subsection{Washing of Agarose Plugs after Cell Lysis}

For solidification, $1.5 \mathrm{~mL}$ tubes in a water bath $\left(55^{\circ} \mathrm{C}\right)$ were kept in ice for 15 minutes. Then, $5-15 \mathrm{~mL}$ of sterile ultra-pure water was transferred into each $50 \mathrm{~mL}$ of falcon tubes. Afterward, lysis solution II was aspirated and the agarose plugs were transferred carefully with a spatula into these falcon tubes and were incubated in a shaking water bath at $50^{\circ} \mathrm{C}$ for 15 minutes. Ultra-pure water was fully aspirated. Thereafter, $15 \mathrm{~mL}$ of tris-EDTA buffer was transferred into falcon tubes and they were incubated at $50^{\circ} \mathrm{C}$ with shaking at 15 minutes. This washing step was performed thrice (12).

\subsection{Cutting the Whole DNA with the NotI-HF ${ }^{\mathrm{TM}}$ Re- striction Enzyme in the Agarose Plugs}

The agarose plugs containing DNA were cut in the ratio of $1 / 4$ and were placed into a $100 \mu \mathrm{L}$ fresh enzyme buffer at $37^{\circ} \mathrm{C}$ for 10 minutes. Next, $100 \mu \mathrm{L}$ of 1 Xbuffer solution was prepared with $100 \mu \mathrm{m} / \mathrm{mL}$ bovine serum albumin (Sigma-Aldrich, USA) and 20 units of fast digest NotI-HF ${ }^{\mathrm{TM}}$ (BioLabs 20,000 U/mL, England) and the genomic DNA embedded in agarose plugs were digested with the NotI$\mathrm{HF}^{\mathrm{TM}}$ at $37^{\circ} \mathrm{C}$ for 30 minutes. After incubation, the tubes were held at $4^{\circ} \mathrm{C}$ for 15 minutes (12).

\subsection{Loading the Agarose Plugs into Gel and Elec- trophoresis}

High molar mass restriction fragments were observed by electrophoresis using $1 \%(\mathrm{w} / \mathrm{v})$ pulsed-field grade agarose (Bio-Rad, USA) prepared with 0.5 X TBE in a CHEF-Mapper PFGE system (Bio-Rad, USA). The separation of the restriction fragments was carried out following running conditions: $6 \mathrm{~V} / \mathrm{cm}^{2}$ via $120^{\circ}$ angle of impact for 24 hours at $14^{\circ} \mathrm{C}$ with 5 - 40 seconds pulse times. The gel was stained with 
ethidium bromide ( $5 \mu \mathrm{g} / \mathrm{mL}$, Sigma-Aldrich, USA) and then destained with sterile deionized water $(12,15)$. The band profile of the bioluminescent strains for the NotI-HF ${ }^{\mathrm{TM}}$ restriction enzyme was analyzed using Bio-Profil-1D++ software (Vilber Lourmat, Deutschland) at 10\% homology coefficient. Dendrograms belonging to the PFGE band pro- files were generated based on the Unweighted Pair-Group Method with Arithmetic Mean (UPGMA) (Vilber Lourmat).

\section{Results}

Table 1 shows the 10 different bioluminescent strains used in the present study(9).

Table 1. Bioluminescent Strains Used in the Present Study and their Accession Numbers together with the Sources, Depths, and Coordinates of the Sampling Dates

\begin{tabular}{|c|c|c|c|c|c|}
\hline $\begin{array}{l}\text { Isolation Date } \\
\text { of Strains } \\
\end{array}$ & Isolate & $\begin{array}{c}\text { Accession } \\
\text { Number }\end{array}$ & Source & Coordinate & Depth, $\mathrm{m}$ \\
\hline 30 March 2007 & & & & & $0-15$ \\
\hline V.gigantis & SW15 & JF412215 & Seawater & $38^{\circ} 29^{\prime} 03^{\prime \prime} \mathrm{N}-26^{\circ} 47^{\prime} 05^{\prime \prime} \mathrm{E}$ & \\
\hline V.gigantis & SWLiman & JF 412216 & Seawater & $38^{\circ} 27^{\prime} 22^{\prime \prime} \mathrm{N}-27^{\circ} 09^{\prime} 65^{\prime \prime} \mathrm{E}$ & \\
\hline A. fischeri & SW22 & JF412240 & Seawater & $38^{\circ} 25^{\prime} 30^{\prime \prime} \mathrm{N}-26^{\circ} 58^{\prime} 60^{\prime \prime} \mathrm{E}$ & \\
\hline V.gigantis & SeLu25 & JF412217 & Sediment & $38^{\circ} 23^{\prime} 50^{\prime \prime} \mathrm{N}-26^{\circ} 39^{\prime} 00^{\prime \prime} \mathrm{E}$ & \\
\hline 22 January 2008 & & & & & $0-15$ \\
\hline A. fischeri & S2W23 & JF412241 & Seawater & $38^{\circ} 25^{\prime} 09^{\prime \prime} \mathrm{N}-27^{\circ} 02^{\prime} 86^{\prime \prime} \mathrm{E}$ & \\
\hline V. gigantis & S2W42 & JF412218 & Seawater & $38^{\circ} 24^{\prime} 58^{\prime \prime} \mathrm{N}-26^{\circ} 56^{\prime} 88^{\prime \prime} \mathrm{E}$ & \\
\hline V.gigantis & S2W9 & JF412219 & Seawater & $38^{\circ} 34^{\prime} 99^{\prime \prime} \mathrm{N}-26^{\circ} 39^{\prime} 00^{\prime \prime} \mathrm{E}$ & \\
\hline A. logei & Se2Lu45-2 & JF412238 & Sediment & $38^{\circ} 25^{\prime} 03^{\prime \prime} \mathrm{N}-27^{\circ} 06^{\prime} 09^{\prime \prime E}$ & \\
\hline V.gigantis & Se2Lu48 & JF412223 & Sediment & $38^{\circ} 24^{\prime} 75^{\prime \prime} \mathrm{N}-26^{\circ} 58^{\prime} 90^{\prime \prime} \mathrm{E}$ & \\
\hline 17 April 2008 & & & & & $0-15$ \\
\hline V.gigantis & S3W46 & JF412220 & Seawater & $38^{\circ} 26^{\prime} 70^{\prime \prime} \mathrm{N}-27^{\circ} 06^{\prime} 10^{\prime \prime} \mathrm{E}$ & \\
\hline V.gigantis & S3W28 & JF412221 & Seawater & $38^{\circ} 23^{\prime} 50^{\prime \prime} \mathrm{N}-26^{\circ} 55^{\prime} \mathrm{OO}$ "E & \\
\hline V.gigantis & S3W2 & JF412222 & Seawater & $38^{\circ} 40^{\prime} 90^{\prime \prime} \mathrm{N}-26^{\circ} 34^{\prime} 90^{\prime \prime} \mathrm{E}$ & \\
\hline V. gigantis & Se3Lu25 & JF412224 & Sediment & $38^{\circ} 23^{\prime} 50^{\prime \prime} \mathrm{N}-26^{\circ} 39^{\prime} 00^{\prime \prime E}$ & \\
\hline 06 August 2008 & & & & & $0-15$ \\
\hline V.harveyi & Se4Lu24 & JF412244 & Sediment & $38^{\circ} 26^{\prime} 22^{\prime \prime} \mathrm{N}-27^{\circ} 04^{\prime} 68^{\prime \prime} \mathrm{E}$ & \\
\hline V. orientalis & Se4Lu49-2 & JF412251 & Sediment & $38^{\circ} 24^{\prime} 35^{\prime \prime} \mathrm{N}-26^{\circ} 58^{\prime} 20^{\prime \prime} \mathrm{E}$ & \\
\hline V.azureus & Se4Lu15 & JF412235 & Sediment & $38^{\circ} 29^{\prime} 03^{\prime \prime} \mathrm{N}-26^{\circ} 47^{\prime} 05^{\prime \prime} \mathrm{E}$ & \\
\hline 30 March 2007 & & & & Between $38^{\circ} 37^{\prime} 00^{\prime \prime} \mathrm{N}-26^{\circ} 42^{\prime} 20^{\prime \prime} \mathrm{E}$ and $38^{\circ} 37^{\prime} 45^{\prime \prime} \mathrm{N}-26^{\circ} 43^{\prime} 30^{\prime \prime} \mathrm{E}$ & 67 \\
\hline V.gigantis & FU-10 & JF412225 & Mullus barbatus (internal area) & & \\
\hline V.gigantis & FU-9 & JF412226 & Diplodus annularis (gill) & & \\
\hline V. lentus & FU-7 & JF461265 & Alloteuthis subulata (internal area) & & \\
\hline 30 March 2007 & & & & & 50 \\
\hline A. logei & U-6 & JF412239 & Merluccius merluccius (intestine content) & Between $38^{\circ} 32^{\prime} 30^{\prime \prime} \mathrm{N}-26^{\circ} 45^{\prime} 50^{\prime \prime} \mathrm{E}$ and $38^{\circ} 31^{\prime} 45^{\prime \prime} \mathrm{N}-26^{\circ} 45^{\prime} 20^{\prime \prime} \mathrm{E}$ & \\
\hline P. kishitanii & $\mathrm{X}-8$ & JF412253 & Zeus faber(surface) & Between $38^{\circ} 26^{\prime} 50^{\prime \prime} \mathrm{N}-26^{\circ} 41^{\prime} 00^{\prime \prime} \mathrm{E}$ and $38^{\circ} 26^{\prime} 00^{\prime \prime} \mathrm{N}-26^{\circ} 39^{\prime} 45^{\prime \prime E}$ & \\
\hline S. woodyi & $X-7$ & JF412255 & Pagellus erythrinus (internal area) & & \\
\hline 17 April 2008 & & & & Between $38^{\circ} 34^{\prime} 40^{\prime \prime} \mathrm{N}-26^{\circ} 46^{\prime} 10^{\prime \prime} \mathrm{E}$ and $38^{\circ} 33^{\prime} 45^{\prime \prime} \mathrm{N}-26^{\circ} 46^{\prime} 55^{\prime \prime} \mathrm{E}$ & $42-44$ \\
\hline V.gigantis & E-14 & JF412227 & Lepidotrigla cavillone (gill) & & \\
\hline V.gigantis & E-16 & JF412228 & Boops boops(surface) & & \\
\hline V.gigantis & E-15 & JF412229 & D. annularis (surface) & & \\
\hline V.gigantis & $\mathrm{E}-10$ & JF412230 & Citharus linguatula (gill) & & \\
\hline V.gigantis & E-11 & JF412231 & Arnoglossus laterna (internal area) & & \\
\hline A. fischeri & E-4 & JF412242 & P. erythrinus (gill) & & \\
\hline 06 August 2008 & & & & Between $38^{\circ} 34^{\prime} 40^{\prime \prime} \mathrm{N}-26^{\circ} 46^{\prime} 10^{\prime \prime} \mathrm{E}$ and $38^{\circ} 33^{\prime} 45^{\prime \prime} \mathrm{N}-26^{\circ} 46^{\prime} 55^{\prime \prime} \mathrm{E}$ & $42-44$ \\
\hline V. harveyi & $\mathrm{H}-15$ & JF412245 & C. linguatula (internal area) & & \\
\hline V. harveyi & $\mathrm{H}-5$ & JF412246 & Scorpaena notata (internal area) & & \\
\hline V. azureus & $\mathrm{H}-1$ & JF412236 & D. vulgaris (gill) & & \\
\hline V. azureus & $\mathrm{H}-14$ & JF412237 & Trisopterus minutuscapelanus (surface) & & \\
\hline V.harveyi & $\mathrm{H}-11$ & JF412247 & P. bogaraveo (surface) & & \\
\hline V. crassostreae & $\mathrm{H}-7$ & JF412248 & A. laterna (gill) & & \\
\hline V.gigantis & $\mathrm{H}-3$ & JF412232 & M. merluccius (surface) & & \\
\hline V. crassostreae & $\mathrm{H}-12$ & JF412249 & Engraulis encrasicolus (gill) & & \\
\hline V. crassostreae & $\mathrm{H}-19$ & JF412250 & Conger conger(internal area) & & \\
\hline A. fischeri & $\mathrm{H}-18$ & JF412243 & Dentex macrophthalmus (internal area) & & \\
\hline V.gigantis & $\mathrm{H}-2$ & JF412233 & D. annularis (intestine contents) & & \\
\hline V.gigantis & $\mathrm{H}-16$ & JF412234 & B. boops (gill) & & \\
\hline V. orientalis & $\mathrm{H}-9$ & JF412252 & L. cavillone (gill) & & \\
\hline
\end{tabular}


Each different group was evaluated separately in terms of PFGE fragment patterns. Three groups were composed (i.e. V.harveyi, V.gigantis, and other species). As is seen in Figure1, all the V. harveyi strains could be typed with PFGE performed with the NotI-HF ${ }^{\mathrm{TM}}$ restriction enzyme (Figure 1C). As a result of the Notl-HF ${ }^{\mathrm{TM}}$ digestion, 2 main clusters (A and B) with 73\% pattern homology were obtained. The closest strains with respect to genetic resemblance were achieved (i.e. Se4Lu24 and $\mathrm{H}-15$ strains) with $83 \%$ homology. The other strains (i.e. $H$ 5 and $H$-11) demonstrated $80 \%$ pattern homology (Figure 2).

Figure 1. Gel Images of the Forty-One Bioluminescent Strains Obtained From the Pulsed-Field Gel Electrophoresis Analysis With the NotI-HFM Restriction Enzyme
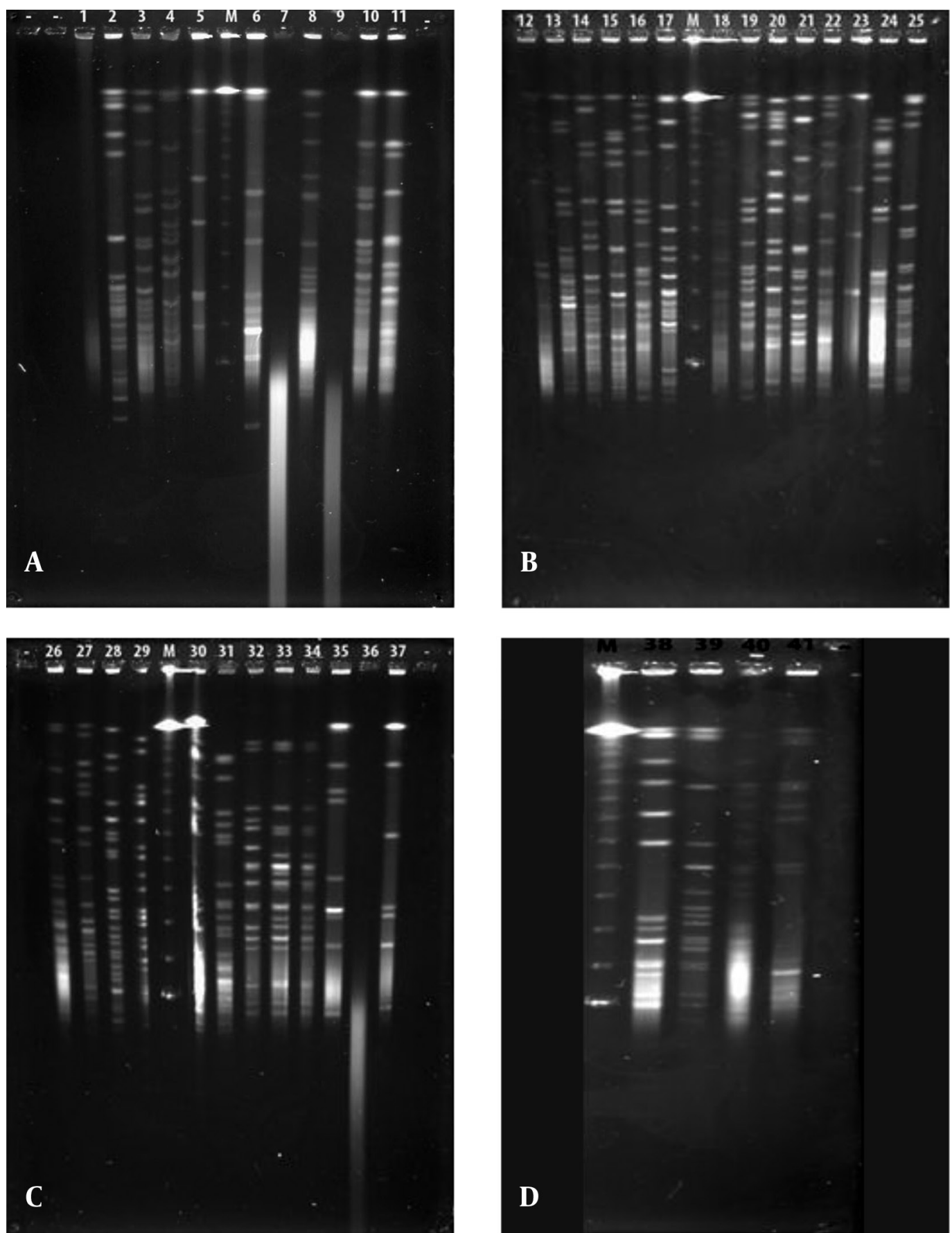

A, V. gigantis (1:E-16, 2:E-10, 3:E-11, 4:H-3, 7:S3W46, 8:S3W28, 9:H-16, 10:E-15, 11:H-2, 25:E-14), A. logei (5:Se2Lu45-2), and A. fischeri (6:S2W23) strains; B, V. gigantis (12:SW15, 13:SWLiman , 14:SeLu25 , 15:S2W42, 16:S2W9 , 17:S3W2, 18:Se2Lu48 , 19:Se3Lu25, 20:FU-10, 21:FU-9), V. lentus (22:FU-7), A. logei (23:U-6), and S. woodyi (24:X-7) strains; C, V. harveyi (26:Se4Lu24, 27:H-15, 28:H-5, 29:H-11), V. orientalis (30:Se4Lu49-2, 31:H-9), V. crassostreae (32:H-7, 33:H-12, 34:H-19), and A. fischeri (35:SW22, 36:E-4, 37:H-18); and D, V. azureus (38:Se4Lu15, 39:H-1, 40:H-14) and P. kishitanii (41:X-8), M: Marker (Lambda Leader, Bio-Rad, USA, 48,5 kb - 1,000 kb). 
Although $20 \mathrm{~V}$. gigantis strains were used in this study, only 17 strains were typed with PFGE performed with the NotI-HF ${ }^{\mathrm{TM}}$ restriction enzyme. As a result of the PFGE analysis for the $V$. gigantis strains, 17 different PFGE fragment patterns were obtained (Figure $1 \mathrm{~A}$ and B). PFGE with the NotI-HF ${ }^{\mathrm{TM}}$ restriction enzyme resulted in 2 main clusters (A and B) and 17 different PFGE fragment patterns. V. gigantis strains S3W46, E-16, and $H-16$ could not be typed. Clusters A and B exhibited 66\% pattern homology. Cluster A consisted of two subclusters (A1 and A2), which displayed 68\% pattern homology, with 16 different PFGE patterns that showed pattern homology between themselves ranging from 68 to $92 \%$. In all the V. gigantis strains, the unrelated strain was SWLiman with $66 \%$ pattern homology. It was determined that the closest strains in terms of PFGE fragment patterns were observed between the SeLu25 and Se2Lu48 strains isolated from sediment and S2W9 and Se3Lu25 with 92\% homology. In subcluster A2, 3 different groups (I, II, and III) were formed with 73\% pattern homology. Thirteen different band patterns were achieved in group I with pattern homology between $81 \%$ and $92 \%$ (Figure 3 ).

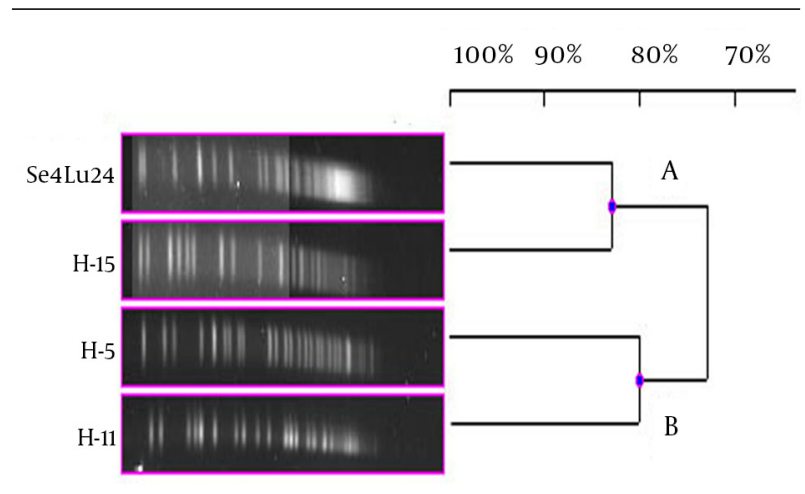

Figure 2. Dendrogram, Showing the Genetic Relationships Between the Bioluminescent V. harveyi Strains Based on the Pulsed-Field Gel Electrophoresis Analysis of the Genomic Restriction Fragments Formed With the NotI-HF'

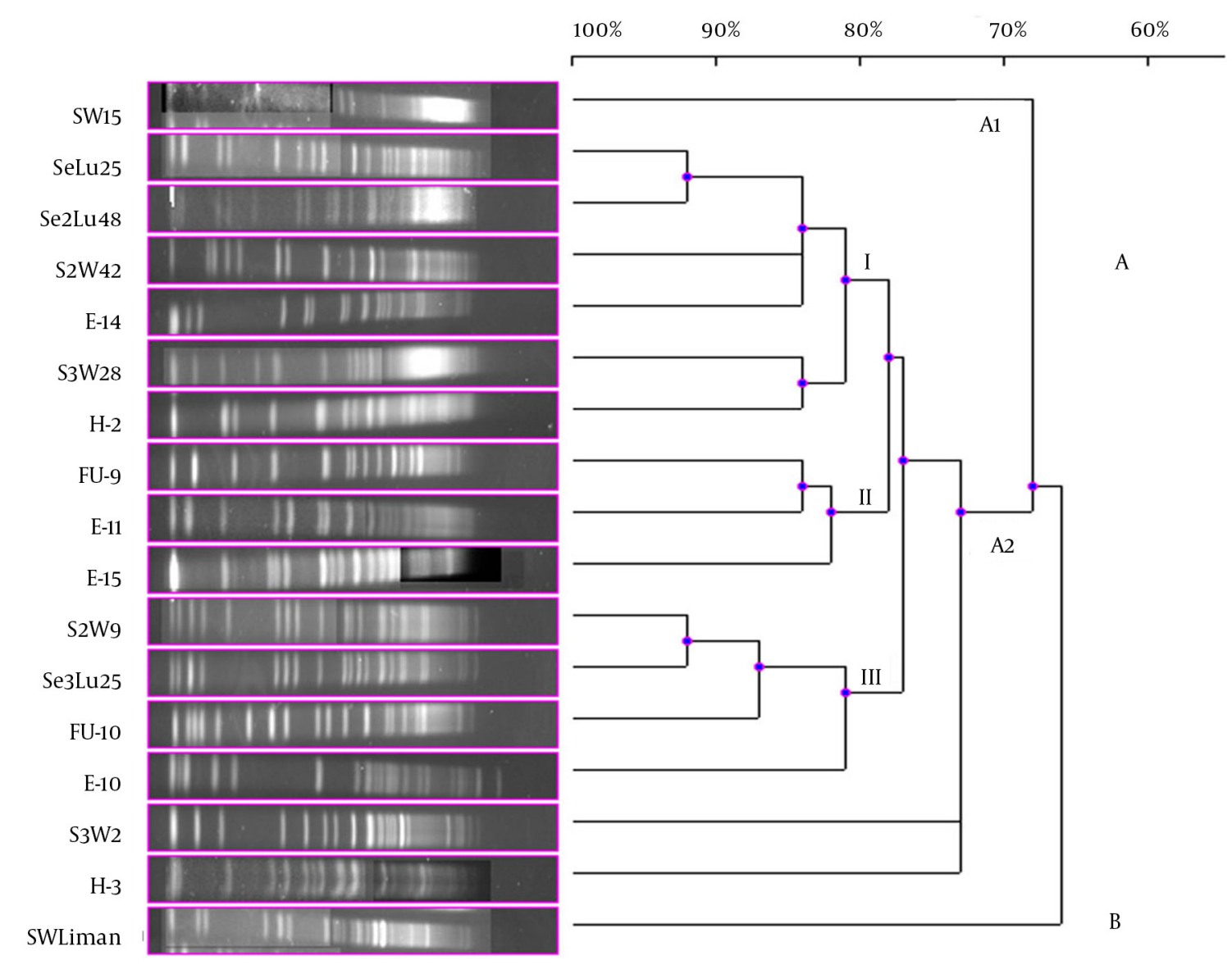

Figure 3. Dendrogram, Showing the Genetic Relationships Between the Bioluminescent V. gigantis Strains Based on the Pulsed-Field Gel Electrophoresis Analysis of the Genomic Restriction Fragments Formed With the NotI-HF ${ }^{\mathrm{TM}}$ 


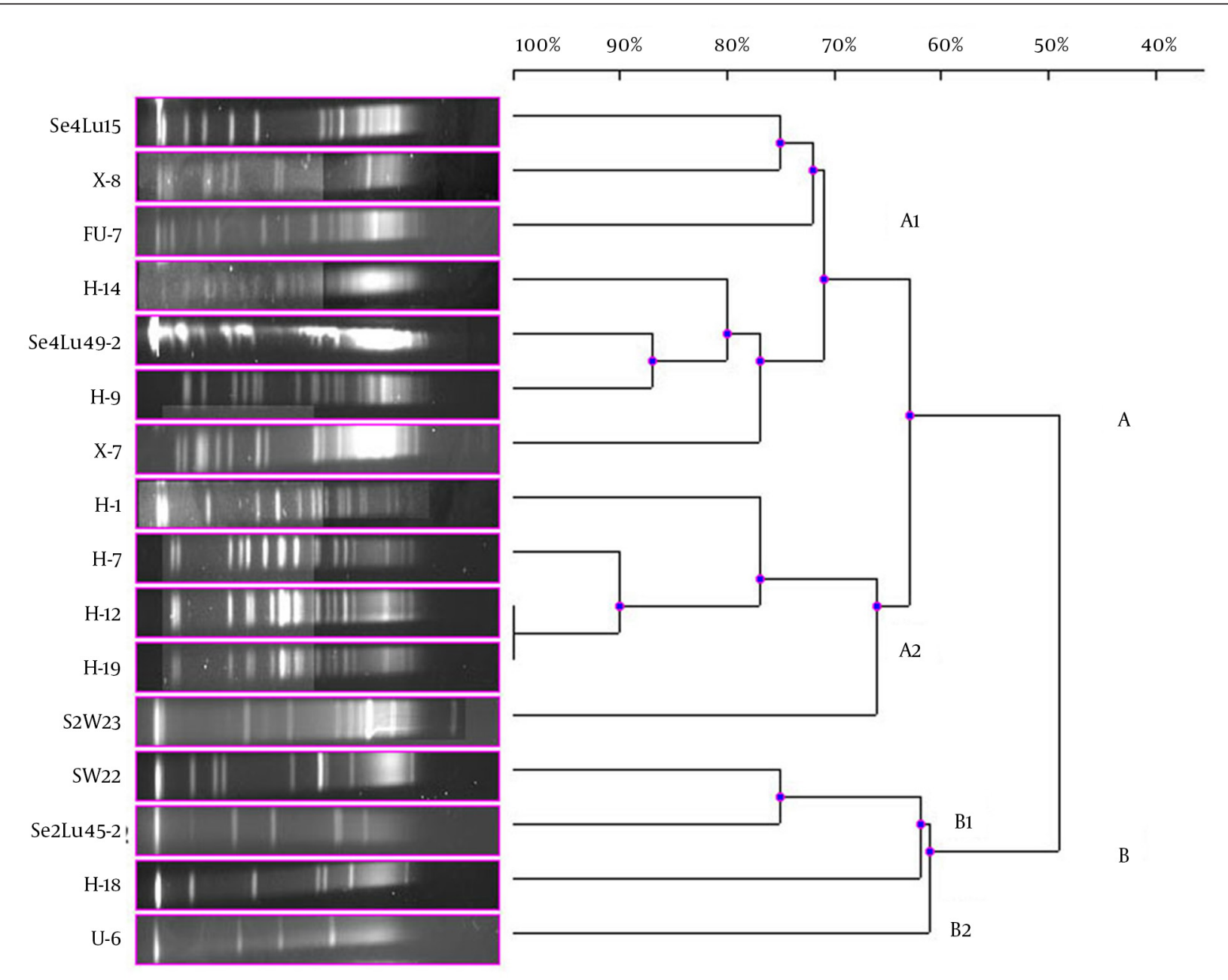

Figure 4. Dendrogram, Showing the Genetic Relationships Between the Bioluminescent V. lentus, V. azureus, V. orientalis, S. woodyi, V. crassostreae, A. fischeri, A. logei, and P. kishitanii Strains Based on the Pulsed-Field Gel Electrophoresis Analysis of the Genomic Restriction Fragments Formed with the NotI-HF ${ }^{\mathrm{TM}}$

In the current study, 41 bioluminescent strains isolated and identified were used and the remaining 17 strains were evaluated together from the point of PFGE fragment patterns with the NotI-HF ${ }^{\mathrm{TM}}$. However, only 16 strains were typed by this technique (Figure 1). The PFGE band pattern for the A. fischeri strain E-4 could not be achieved. In this group, there were $3 \mathrm{~V}$. azureus strains, $3 \mathrm{~V}$. crassostreae strains, $2 \mathrm{~V}$. orientalis strains, 3 A. fischeri strains, $2 \mathrm{~A}$. logei strains, 1 P. kishitanii strain, 1 V. lentus strain, and $1 S$. woodyi strain. In consequence of the NotI-HF ${ }^{\mathrm{TM}}$ digestion of the total genomic DNA, 2 main clusters (A and B) formed with $49 \%$ pattern homology. Considering all the bioluminescent strains in this group, PFGE fragment patterns with genome homology between $61 \%$ and $100 \%$ were achieved. Two V. crassostreae strains (i.e. $H$-12 and $H$-9) exhibited genome homology with the highest percentage(100\%). Also, it was determined that the other V.crassostreae strain (i.e. $H-7)$ was similar to the $H-12$ and $H-9$ strains at a ratio of $90 \%$ pattern homology. While the V. orientalis strains Se4Lu49-2 and $H-9$ had $87 \%$ genome homology, the A. fischeri (S2W23,
SW22, and H-18) and A. logei (Se2Lu45-2 and U-6) strains between each other showed the lowest homology (61\% and $62 \%)$. With the exception of $S 2 W 23$, all the A. strains were located in cluster A (Figure 4).

\section{Discussion}

Within the scope of our study, the genetic diversity of 41 bioluminescent strains was determined. Ten different bioluminescent species were evaluated in terms of genomic polymorphism based on PFGE with the NotI-HF ${ }^{\mathrm{TM}}$ restriction enzyme. Moreover, so far, there have been no data indicating that the V.lentus and $V$. crassostreae strains are bioluminescent. It is, therefore, believed that these data will contribute to a better understanding of the evolution of bioluminescence. There are a large number of techniques for the characterization of bacterial species and also the evaluation of DNA similarity between two bacterial strains. The first definition method was DNADNA hybridization, but it is not suitable for the routine identification or determination of the genetic polymor- 
phism of isolates because, although it is necessary to exhibit new bacterial genera and species, this technique is complex and limited to a few laboratories and also there is a dearth of relevant information (19).

To investigate clonal diversity and relationship between bacteria, PFGE with the highest discriminatory power has been used (12). PFGE is considered the gold standard because the structural integrity of the chromosome of the bacteria embedded in agarose plugs is not destroyed and the whole genome is profiled via cutting with the restriction enzyme. It has been proven that PFGE genomic DNA analysis is more discriminative in exhibiting phylogenetic diversity than analyses based on phenotype characterization (20). The genetic diversity and genotyping of some bioluminescent Vibrio isolates were determined by cutting their whole genome with 5 different restriction enzymes (i.e. ApaI, EagI, NotI-HF ${ }^{\mathrm{TM}}$, SpeI, and SmaI). DNA profiling with PFGE was introduced by Suwanto et al. in 1998 (13). In addition, some other studies have revealed further data relating to the PFGE analysis of bioluminescent bacteria $(3,21)$. In the present study, we determined clonal diversity and relationship using PFGE among bioluminescent $S$. woodyi strains (15) and V. gigantis strains (9). Nonetheless, to the best of our knowledge, the existing literature lacks research on the determination of genetic diversity via PFGE among bioluminescent $A$. fischeri, A. logei, V. azureus, V. orientalis, V. lentus, and V. crassostreae strains. The current study is, therefore, the first of its kind to report this genetic diversity. It is also deserving of note that the PFGE analysis of the $V$. gigantis strains with the NotI-HF ${ }^{\mathrm{TM}}$ has been carried out for the first time in the present study. The findings are very significant since $V$. gigantis was first reported as a bioluminescent strain in one of our previous studies (9). For assays, the NotI-HF ${ }^{\mathrm{TM}}$ was selected in light of a study performed by Suwanto et al. (13). The selection of the restriction enzyme is a critical variable in the PFGE process. Clonal diversity and relationship among the isolates are determined based on the restriction fragment band pattern. Accordingly, the fragments should be workable in number and distribution.

In the current study, 4 out of the 41 bioluminescent strains could not be typed by PFGE with the NotI-HF ${ }^{\mathrm{TM}}$ and although optimization assays were made and repeated three times for all the PFGE experiments, a smear appeared. Similarly, in a study performed by Eddabra et al. (21), 5 of the 30 Vibrio isolates could not be typed by PFGE with the NotI-HF ${ }^{\mathrm{TM}}$ due to the methylation of genomic DNA or DNA degradation during the process. In our study, because all the bioluminescent strains were isolated from different sources and depths, our findings reconfirm the heterogeneous structure of bioluminescent strains (21). In consequence of PFGE assays, 17 different band patterns were obtained as was expected. These differences obtained were not determined by phenotypic characterization. Whereas our previous study had determined that the bioluminescent $V$. gigantis strains had a few differences in their phenotypes, the findings of the present study revealed that the $V$. gigantis strains had a high incidence of polymorphism when the whole genome was analyzed via PFGE with the NotI-HF ${ }^{\mathrm{TM}}$.

The highest percentage of genome similarity in the $17 \mathrm{~V}$. gigantis strains used in the current experiment was found to be $92 \%$. SeLu 25 and Se2Lu48 were two sediment strains isolated from different seasons and stations but from the same depth. Additionally, S2W9 and Se3Lu25 were seawater and sediment strains, respectively, and even though they were isolated from the same depth, their isolation sources were different. In contrast, the SeLu25-Se2Lu48 (92\%) and S2W9-Se3Lu25(92\%) strains were found to be genetically closer than $\mathrm{H}-2$, FU-9, and E-15 (78\%) isolated from the same fish species. Although SW15, SWLiman, and SeLu25 were isolated from the same depth in the same season, it was become evident that SWLiman was different from all other V. gigantis strains and it showed 66\% genome similarity with the others. In addition, it was determined that only bioluminescent $V$. gigantis strains showed distribution in Diplodus annularis and they were not completely identical in terms of whole genome and also genotypic similarity among them was at a ratio of $78 \%$.

As a result of the PFGE assays, all the $V$. harveyi strains were typed and 4 different PFGE band patterns were achieved. As well as being isolated in the same season; while sediment sample Se4Lu24 was obtained from a depth of 0 - 15 meters, the other V. harveyi strains (i.e. H-15, $H-5$, and $H-11$ ) were taken from a depth of $42-44$ meters. In consequence of the PFGE assay, these strains were divided into 2 main clusters with 73\% of pattern homology. Contrary to expectation, the closest genome similarity (83\%) was achieved from 2 strains, Se4Lu24 (a sediment isolate) and $\mathrm{H}-15$ (isolated from Citharus linguatula). To determine why bioluminescence has come into being in the evolutionary process, some studies have been performed, especially on the $V$. harveyi strains, and significant results have been obtained (22). Hence, the determination of the genetic proximity of these strains to one another will contribute greatly to the understanding of these mechanisms and we hope that our findings will play a part in future investigations.

In the present study, the remaining 17 bioluminescent strains were examined together. A. fischeri E-4 strain was not typed. On dendrogram consisting of the 2 main clusters, it was observed that the Alivibrio strains were gathered in cluster $B$ and the other bioluminescent strains were in cluster A. Then again, it was determined that the Aliivibrio strains were different from the other bioluminescent Alivibrio and Photobacterium species and their genome similarity was $49 \%$. Only the A. fischeri S2W23 strain was located in cluster A and it showed 63\% of genome similarity with these species in a different subcluster of cluster A. The Aliivibrio genus was incorporated in the Vibrionaceae family in 2007 in the sequel of a study performed by Urbanczyk et al. (1), who reported that some Vibrio species were different from the species in the Vibrionaceae family in terms of phylogenetic and phenotypic 
features. These results chime in with the findings of our study.

A similar situation was observed in the bioluminescent strain $V$. azureus. The results showed that $3 \mathrm{~V}$. azureus strains emerged in different subclusters in cluster $A$ and each of them displayed higher genome homology with different bioluminescent strains than similarity among themselves. Contrary to this, a high PFGE band pattern resemblance was determined in the $V$. orientalis and $V$. crassostreae strains. Based on the band pattern, especially 2 V. crassostreae strains (i.e. $H-12$ and $H$-19) were completely identical and the other $V$. crassostreae strain (i.e. H-7) exhibited 90\% genome homology with these 2 strains. The V. orientalis strains Se4Lu49-2 and H-9 were more similar to each other in terms of the genomic feature than the other species, and the homology of the band pattern was $87 \%$.

The V. lentus, P. kishitanii, and V. azureus strains, which were first reported in the literature in 2001, 2007, and 2010 , respectively, were located in the same subcluster in the present study. Our results showed that especially the new bioluminescent strains, i.e. P. kishitanii and V. azureus, had $75 \%$ of the PFGE band pattern homology. The V.lentus strains were isolated and identified for the first time in 2001 and characterized by various research groups in subsequent years $(23,24)$. However, none of these studies showed that this strain was bioluminescent. Our findings revealed that the $V$. lentus strains could also show bioluminescence and had genome similarity at a ratio of $75 \%$ with the bioluminescent species recently reported in the literature. In addition, the PFGE analysis demonstrated that the $V$. lentus strains emerged separately from the other bioluminescent strains in the different subclusters.

The PFGE genomic DNA analysis is more discriminative in revealing genetic diversity and polymorphism among related species than analyses based on phenotypic characterization. A study performed by Suwanto (20) revealed that 25 isolates characterized by physiological analysis came together under 2 Vibrio species. Moreover, when the PFGE analysis with the NotI-HF ${ }^{\mathrm{TM}}$ was performed, 13 different genotypes were ingenerated. The analyses of the phenotypic characterization of these strains have verified that the discriminatory power of PFGE is higher than that of the other techniques. Our results revealed that 37 bioluminescent strains belonged to 4 different genera and 10 different species had 36 different genotypes.

To our knowledge, there have not been any PFGE studies including 4 bioluminescent genera. The present study is, therefore, the first of its kind in terms of its scope. With the discovery of new bioluminescent species exhibiting new bioluminescent features, we hope that the findings of the present study will contribute to a better understanding of the mechanism and evolution of bioluminescence and polymorphism in different bioluminescent strains. The strains investigated in the current study were isolated and identified from different marine sources and consisted of the 4 bioluminescent genera identified so far. Moreover, in the present study, the PFGE assay was performed by using the NotI-HF ${ }^{\mathrm{TM}}$ restriction enzyme and the genetic diversity of 37 bioluminescent strains was demonstrated.

\section{Acknowledgements}

The authors would like to extend their thanks to the Izmir Institute of Technology, Biotechnology, and Bioengineering Research as well as the Application Center. Many thanks are also due to Mert Sudagidan for molecular assays.

\section{References}

1. Urbanczyk H, Ast JC, Higgins MJ, Carson J, Dunlap PV. Reclassification of Vibrio fischeri, Vibrio logei, Vibrio salmonicida and Vibrio wodanis as Aliivibrio fischeri gen. nov., comb. nov., Aliivibrio logei comb. nov., Aliivibrio salmonicida comb. nov. and Aliivibrio wodanis comb. nov. Int J Syst Evol Microbiol. 2007;57(Pt 12):2823-9.

2. Kita-Tsukamoto K, Wada M, Yao K, Kamiya A, Yoshizawa S, Uchiyama N, et al. Rapid identification of marine bioluminescent bacteria by amplified $16 \mathrm{~S}$ ribosomal RNA gene restriction analysis. FEMS Microbiol Lett. 2006;256(2):298-303.

3. Ast JC, Cleenwerck I, Engelbeen K, Urbanczyk H, Thompson FL, De Vos P, et al. Photobacterium kishitanii sp. nov., a luminous marine bacterium symbiotic with deep-sea fishes. Int J Syst Evol Microbiol. 2007;57(Pt 9):2073-8

4. Yoshizawa S, Wada M, Kita-Tsukamoto K, Yokota A, Kogure K. Photobacterium aquimaris sp. nov., a luminous marine bacterium isolated from seawater. Int J Syst Evol Microbiol. 2009;59(Pt 6):1438-42.

5. Yoshizawa S, Wada M, Kita-Tsukamoto K, Ikemoto E, Yokota A Kogure K. Vibrio azureus sp. nov., a luminous marine bacterium isolated from seawater. Int J Syst Evol Microbiol. 2009;59(Pt 7):1645-9.

6. Yoshizawa S, Wada M, Yokota A, Kogure K. Vibrio sagamiensis sp nov., luminous marine bacteria isolated from sea water. $J$ Gen Appl Microbiol.2010;56(6):499-507.

7. Urbanczyk H, Ast JC, Kaeding AJ, Oliver JD, Dunlap PV. Phylogenetic analysis of the incidence of lux gene horizontal transfer in Vibrionaceae.J Bacteriol. 2008;190(10):3494-504.

8. Yoshizawa S, Karatani H, Wada M, Yokota A, Kogure K. Aliivibrio sifiae sp. nov., luminous marine bacteria isolated from seawater. J Gen Appl Microbiol. 2010;56(6):509-18.

9. Ersoy Omeroglu E, Karaboz I. Characterization and genotyping by pulsed-field gel electrophoresis (PFGE) of the first bioluminescent Vibrio gigantis strains. Afr J Microbiol Res. 2012;6(43):7111-22.

10. Le Roux F, Goubet A, Thompson FL, Faury N, Gay M, Swings J et al. Vibrio gigantis sp. nov., isolated from the haemolymph of cultured oysters (Crassostrea gigas). Int J Syst Evol Microbiol. 2005;55(Pt 6):2251-5.

11. Stabili L, Giangrande A, Pizzolante G, Caruso G, Alifano P. Characterization of vibrios diversity in the mucus of the polychaete Myxicola infundibulum (Annellida, Polichaeta). Microb Ecol. 2014;67(1):186-94.

12. Durmaz R, Otlu B, Koksal F, Hosoglu S, Ozturk R, Ersoy Y, et al. The optimization of a rapid pulsed-field gel electrophoresis protocol for the typing of Acinetobacter baumannii, Escherichia coli and Klebsiella spp. Jpn J Infect Dis. 2009;62(5):372-7.

13. Suwanto A, Yuhana M, Herawaty E, Angka SL. Genetic diversity of luminous Vibrio isolated from shrimp larvae. In: Flegel TW editor. Advances in shrimp biotechnology. Bangkok, Thailand: National Center for Genetic Engineering and Biotechnology; 1998. pp. 217-24.

14. Oh HS, Kum KA, Kim EC, Lee HJ, Choe KW, Oh MD. Outbreak of She wanella algae and Shewanella putrefaciens infections caused by a shared measuring cup in a general surgery unit in Korea. Infect Control Hosp Epidemiol. 2008;29(8):742-8.

15. Ersoy Omeroglu E, Karaboz I, Sudagidan M. Characteristics and genetic diversity of bioluminescent Shewanella woodyi strains 
isolated from the Gulf of Izmir, Turkey. Folia Microbiol (Praha). 2014;59(1):79-92.

16. Cameron DN, Khambaty FM, Wachsmuth IK, Tauxe RV, Barrett TJ. Molecular characterization of Vibrio cholerae 01 strains by pulsedfield gel electrophoresis. J Clin Microbiol.1994;32(7):1685-90.

17. Ersoy Omeroglu E. Isolation, phenotypic and molecular characterization of bioluminescent bacteria from Izmir Bay. Ege University, Doctoral thesis; 2011.

18. Liu PC, Chuang WH, Lee KK. Infectious gastroenteritis caused by Vibrio harveyi (V. carchariae) in cultured red drum, Sciaenops ocellatus. J Appl Ichthyol. 2003;19(1):59-61.

19. Gevers D, Cohan FM, Lawrence JG, Spratt BG, Coenye T, Feil EJ, et al. Opinion: Re-evaluating prokaryotic species. Nat Rev Microbiol. 2005;3(9):733-9.

20. Suwanto A. Genetic diversity of ampicillin-resistant Vibrio iso- lated from various stages of tiger shrimp larvae development. Biotropia. 2000;(15):36-47.

21. Eddabra R, Prevost G, Scheftel JM. Rapid discrimination of environmental Vibrio by matrix-assisted laser desorption ionization time-of-flight mass spectrometry. Microbiol Res. 2012;167(4):226-30.

22. Czyz A, Plata K, Wegrzyn G. Stimulation of DNA repair as an evolutionary drive for bacterial luminescence. Luminescence. 2003;18(3):140-4.

23. Macian MC, Ludwig W, Aznar R, Grimont PA, Schleifer KH, Garay E, et al. Vibrio lentus sp. nov., isolated from Mediterranean oysters. Int J Syst Evol Microbiol. 2001;51(Pt 4):1449-56.

24. Farto R, Armada SP, Montes M, Guisande JA, Perez MJ, Nieto TP. Vibrio lentus associated with diseased wild octopus (Octopus vulgaris). J Invertebrate Pathol. 2003;83(2):149-56. 